England to become an assistant to the late Mr. W. H. Barker, then reader in geography at Manchester. After the latter's death in 1929, Mr. Fitzgerald was acting head of the Department during the interregnum, and soon after the election of Prof. Fleure to the newly created chair became senior lecturer in geography and has retained that position to the present time. Mr. Fitzgerald has travelled widely and is the author of a standard work on the regional geography of Africa. His views on some fundamental concepts of modern geography have been set forth in a series of three articles in NATURE, the last of which appears in this issue.

\section{State Scientific Research in Great Britain}

A statement of the existing Government organization has now been issued as a White Paper under the title "Scientific Research and Development" (Cmd. 6514. London : H.M. Stationery Office. 2d. net), to provide a factual background for the discussion of the part which the Government can play in this field after the War. After describing briefly the constitution and functions of the Development Commission and of the three Committees of the Privy Council for Scientific and Industrial Research, for Medical Research and for Agricultural Research, and the organizations working under them, the statement outlines the existing organization in each of those Government Departments which is faced with special scientific problems peculiar to its own field of activities and administers research and development organiza. tions of its own or has scientific advisers on its staff. A further section of the White Paper describes the provision made by the Government for financial assistance to the universities for fundamental research, and the final section, on co-ordination and control organization, deals with the Scientific Advisory Committee of the War Cabinet and with the responsibilities of the Lord President of the Council in relation to scientific research. Although the statement includes no account of the special war-time activities of the research councils or of the research and development organizations of the Service and Supply Dopartments (including, for this purpose, the Ministry of Home Security) or of the many establishments working under their direction, it provides a very convenient picture of the structure of the Government organization for research in handy reference form.

\section{Rail and Road Transport in Britain}

THe third report from the Select Committee on National Expenditure for the session 1943-44, dealing with rail and road transport in Great Britain, well emphasizes the vital importance of transport in the war effort. The present agreement between the Government and the railway companies, which became operative on January 1, 1941, has given the Government a direct interest in costs of railway operation, and the report notes that receipts have increased, in round figures, by $£ 95,500,000$, while expenses have risen by $£ 48,250,000$ a year between 1940 and 1942. A close watch over railway operating expenditure is clearly essential from the point of view of national economy. On particular points, the Committee is disturbed at the congestion on the railways, in spite of the relief which the transfer of some traffic to the roads has brought. The congestion has aggravated an already serious coal situation, because filled wagons at colliery sidings have often not been movable, and the first recommendation is that the call-up of railway workers should cease, and that a steady influx of labour should be directed to the railways. Zoning has effected appreciable economies in railway transport. As regards passenger traffic, the Committee recommends that immediate consideration be given to the formulation of plans for the compulsory staggering of holidays. With regard to road transport, it is recommended that the Ministry of War Transport should immediately and closely re-examine the present freight charges and adjust them where necessary. The report also considers the Road Haulage Organisation, and the criticism of the scheme from the industry and the Ministry's reply. There is much evidence of extravagant use of vehicles and capacity, and the report finally recommends that a close scrutiny be made of the work of divisional and area haulage officers, and more particularly that of unit controllers, with the view of more economical use being made of lorries and their carrying capacity.

\section{British Urion Catalogue of Periodicals}

At the Association of Special Libraries and Information Bureaux Conference held in November 1942, following a paper presented by Mr. Theodore Bisterman "On a Proposed Union Catalogue of Periodicals", the Association was requested to consider the possibility of publishing a union catalogue of British and foreign periodical publications on all subjects and of all dates, the location of which is traced in a library in the British Isles. A committee under the chairmanship of Dr. Luxmoore Newcombe, librarian of the National Central Library, and including members of the Library Association, the British Museum staff, the Joint Standing Committee on Library Co-operation and the Science Museum Library, satisfied itself that the project was practicable, and that the resulting Catalogue would prove an invaluable bibliographical tool. It was estimated that the compilation of the preliminary check-list, prepared from existing union and other lists and catalogues, would take about five years and that this check-list, in itself, would be of the utmost value. Moreover, it was clear that the planning of post-war rehabilitation of British library services must be based on an assessment of their present holdings, and for this alone the check-list would provide most useful help.

The project was submitted to the trustees of the Rockefeller Foundation, who have agreed to appropriate, for a period of five years beginning February 1, 1944, up to $£ 14,000$ to the Association of Special Libraries and Information Bureaux for the British Union Catalogue of Periodicals. Although the work will remain under the financial and general direction of the Association, the actual operative control of the production of the Catalogue will be in the hands of an executive council representative of the leading British library and bibliographical interests. The first meeting of this Council was held on March 28, when Mr. Theodore Besterman was appointed editor. Work on the compilation of the check-list will begin at once.

\section{Australian Forestry in War-time}

WIтн the Dominion of Australia in the 'front line' and the necessity to conserve shipping space, timber has proved more important to Australia in this War than in that of 1914-18 (Australian Forestry, 7 ; 1943. Pilpel and Co., Perth, Western Australia). When a country's industrial effort expands, its timber demands expand also, as already exemplified in the 